\title{
Clinical, Hematological and Biochemical Health Benefit Effects of Hibiscus sabdariffa Lin Dried Calyces Beverage in Human
}

\author{
Ghislain Maffo Tazoho', Inocent Gouado²*, Mathieu Ndomou ${ }^{2}$, Salomon Tchuandom Bonsi ${ }^{3}$, \\ Yvonne Mbaduet Wamba ${ }^{4}$, Esther Etengeneng Agbor ${ }^{1}$ \\ ${ }^{1}$ Department of Biochemistry, Faculty of Science, University of Dschang, Dschang, Cameroon \\ ${ }^{2}$ Department of Biochemistry, Faculty of Science, University of Douala, Douala, Cameroon \\ ${ }^{3}$ Penka-Michel's District Hospital Laboratory, Penka-Michel, Cameroon \\ ${ }^{4}$ Espace Priorité Santé du Cameroun Health Center, Dschang, Cameroon \\ Email: "gouadoi@yahoo.fr
}

Received 23 February 2016; accepted 26 April 2016; published 29 April 2016

Copyright (C) 2016 by authors and Scientific Research Publishing Inc.

This work is licensed under the Creative Commons Attribution-NonCommercial International License (CC BY-NC).

http://creativecommons.org/licenses/by-nc/4.0/

(c) () (9) Open Access

\section{Abstract}

Background/Objective: This study was carried out to investigate the health benefit effects of $\mathrm{Hi}$ biscus sabdariffa Lin (H. sabdariffa L.) dried calyces beverage on some clinical, biochemical and hematological parameters in humans. Methods: The dried calyces were harvested in the two regions (Adamaoua and West) of Cameroon. The proximate, mineral composition and phytochemical screening were evaluated. A standardized extraction procedure was set up and from the calyces; we prepared a drink for 32 male volunteers' subjects aged from 21 to 32 years, specially recruited for the experiment. Each participant consumed $500 \mathrm{~mL}$ twice a day (in the morning and in the evening) as supplement beverage during two weeks. The anthropometrics (age, height, weight, body mass index (BMI)), clinical (systolic and diastolic blood pressure), hematological (RBC, Hb, PCV, MCV, MCH, MCHC, WBC, Lymphocytes, MID cells, Granulocytes, platelet and MPV) and biochemical (TC, HDL-C, LDL-C, TG, serum iron, blood glucose, creatinine, urea, ASAT and ALAT) parameters were determined in the blood on days 0 and at the end of each week. Results: Crude protein, lipid, fiber and ash content of calyx ranged respectively from 4.57 - 5.98, 10.10 - 11.33, 20.39 22.30 and $9.15 \%-10.38 \%$ while the levels of minerals were ranged from $512.0-740.6,77.8$ $177.7,52.84-52.85,1.10-2.10,41.2-119.5,3.25-8.20$ and $0.56-17.5 \mathrm{mg} / 100 \mathrm{~g}$ respectively for $\mathrm{Ca}, \mathrm{Mg}, \mathrm{K}, \mathrm{Na}, \mathrm{P}, \mathrm{Fe}$ and $\mathrm{Zn}$. The phytochemical screening tests revealed the presence of alkaloids, flavonoids, tannins, phenols and anthocyanins on methanol and aqueous extracts. A significant increase of RBC, Hb, PCV, MPV, HDL-C, TG and creatinine and a significant decrease of WBC, MID cells, LDL-C and TC $(p<0.05)$ were observed during the study period. Furthermore, there was no significant change on BMI, MCV, MCH, MCHC, lymphocyte, granulocyte, platelet, serum iron, blood

\footnotetext{
${ }^{*}$ Corresponding author.
}

How to cite this paper: Maffo Tazoho, G., Gouado, I., Ndomou, M., Tchuandom Bonsi, S., Mbaduet Wamba, Y. and Agbor, E.E. (2016) Clinical, Hematological and Biochemical Health Benefit Effects of Hibiscus sabdariffa Lin Dried Calyces Beverage in Human. Food and Nutrition Sciences, 7, 383-395. http://dx.doi.org/10.4236/fns.2016.75040 
glucose, ASAT, ALAT and urea levels. Conclusion: H. sabdariffa L. dried calyces from Cameroon are rich sources of crude fibers and minerals. The $H$. Sabdariffa $L$. dried calyces drink can be safely used for people suffering for anemia. It also revealed good cholesterol lowering potential. No hepatoxicity and no kidney damage have been observed as far as serum enzymes were concerned.

\section{Keywords}

\section{Hibiscus sabdariffa Lin, Dried Calyces, Chemical Composition, Health, General Well-Being, Human}

\section{Introduction}

The important role of diets in diseases prevention and health promotion has been clearly mentioned and the health benefits of plant foods are not only attributable to their macro- and/or micronutrients content but also to the presence of phytochemical compounds [1]. These plant foods which might provide therapeutic benefits are generally called "functional foods". The International Life Sciences Institute [2] defined functional foods as "foods that, by virtue of the presence of physiologically active compounds provide a health beyond basic nutrition”. A plethoric of public health guidelines are aimed to recommend generous intakes of plant foods including fruits, vegetable, whole grain cereals and diet low in saturated fatty acids. In many African culture, vegetables form an important part of healthy traditional diet to improve nutrition, boost food security, foster rural development, support sustainable land care an offer health protecting properties [3]. Hibiscus sabdariffa Lin is one of such plant foods of nutritional importance. The Hibiscus calyces have been found to be rich in vitamins, carbohydrate, protein, antioxidant compounds and minerals [4] [5]. These calyces are used to make beverages generally called hibiscus tea [6].

In Cameroon, the Hibiscus calyces beverage, a non-alcoholic local beverage, is generally obtained by boiling calyces in water (often with natural additives such as: pineapple, Cymbopogon citratus) follow by a filtration and a sugar adding. This beverage, easy to make is a very cheaper drink comparatively to soft drink or others fruits juice sold in local market. However, the nutritive value and functional properties of Hibiscus calyces cultivated in Cameroon is not well documented. The consumption of $H$. sabdariffa L. drink tea may have some positive effects on preventing chronic diseases and promoting health or general well-being in consumers. A previous study with this drink tea has shown positive effects on some biochemical parameters such as a significant increase of hemoglobin and significant decrease of total cholesterol level [7]. However, there is a need to investigate more such as the evaluation of the effect of its consumption on hematopoietic system and other biochemical parameters.

Then, this study was aimed to determine the proximate and mineral composition of Hibiscus calyces cultivated in Cameroon and evaluate the effect of their consumption as supplemented-beverage on some clinical, biochemical and hematological parameters in human subjects.

\section{Material and Methods}

\subsection{Study Areas}

The study was conducted in two agro ecological areas, precisely in the high Guinean savanna zone (Adamaoua region of Cameroon) and in the Western high plateaus zone (West region of Cameroon). The Guinean savanna zone records a monomodal rainfall pattern. The mean annual rainfall is approximately $1500 \mathrm{~mm}$ with approximately 150 days of rainfall. The temperature of this zone is of moderate type with a monthly mean ranged between 20 to $26^{\circ} \mathrm{C}$. The Western high plateaus zone is characterized by two seasons with unequal length. The dry season starts in mid-November and end in mid-March while the raining season starts in mid-March and end in mid-November. The temperature is moderately low with a mean of $19^{\circ} \mathrm{C}$ while the rains are abundant with an annually mean of $2000 \mathrm{~mm}$.

\subsection{Plant Material}

H. sabdariffa L. dried calyces were collected close to the farmers from Adamaoua and West regions of Camer- 
oon in 2012 during the harvest period. Dried calyces collected in each area were placed in polyethylene bags and transported to the laboratory. A part of dried calyx was crushed into fine powder for proximate and mineral composition analyses.

\subsection{Hibiscus sabdariffa L. Beverage Preparation}

The H. sabdariffa L. beverage was prepared using the modified method of Maffo et al. [7]. For preparation of 20 litres of tea, $430 \mathrm{~g}$ of dried calyces were previously washed using tap water and boiled in a pot with 12 litres of water for 30 minutes using a gas cooker. After cooling, the mixture was filtered and the red filtrate was obtained. Concomitantly, $1.5 \mathrm{~kg}$ of sugar powder was dissolved in 8 litres of water and boiled for 10 minutes. That solution was added to the red filtrate obtained as described above, and homogenized to obtain the drink. That drink was then kept fridge at $4^{\circ} \mathrm{C}$ using polyethylene bottles of 1.5 litres.

\subsection{Aqueous Extract Preparation}

A small quantity of the drink was set apart and filtered through Whatman filter paper No 1 and the extract was obtained by complete evaporation of water in an oven at $45^{\circ} \mathrm{C}$. The solid extract was used for phytochemical screening.

\subsection{Methanol Extract Preparation}

To prepare the methanol extract, the calyx was crushed into fine powder and $100 \mathrm{~g}$ of it was infused in $400 \mathrm{~mL}$ of methanol. The content was mixed thoroughly and left for 48 hours with two times daily shaking to improve the extraction. Thereafter, the homogenate obtained was then filtered with Whatman filter paper No 1, and the extract was concentrated in a hot air oven at $63^{\circ} \mathrm{C}$. The solid extract was used for phytochemical screening.

\subsection{Phytochemical Screening}

The secondary metabolites such as alkaloids, flavonoids, tannins, phenols, saponins, sterols, triterpenoids and anthocyanins were investigated in the aqueous and methanol extracts using the methods described by Harbone [8].

\subsection{Proximate Composition}

Crude protein, lipid, ash and dry matter were determined according to AOAC method [9]. Briefly, samples were dried at $105^{\circ} \mathrm{C}$ overnight and dry matter was calculated. Total nitrogen (micro-kjeldahl) was determined and protein was calculated as $\mathrm{N} \times 6.25$. Ash content was determined by incinerating samples at $500^{\circ} \mathrm{C}$ to constant weight. Total lipids were determined by extracting a known weight of sample with Ether exhaustively using a soxhlet apparatus. Crude fiber content was determined using Sharer and Kurschner method [10]. Each sample was analysed in triplicate.

\subsection{Mineral Composition}

Minerals were determined in sample extracts, prepared by dry-ashing [11]. The amount of zinc and iron were determined according to the analytical method of atomic absorption spectroscopy [12]. The phosphorus was determined by the ammonium molybdate/ammonium vanadate method of Chapman and Pratt [13]. Calcium and magnesium were determined by the titration method of Chapman and Pratt [14]. Sodium and potassium were determined according to AOAC [9] using flame photometer.

\subsection{Study Subjects}

Thirty two male subjects were recruited for the study (aged 21 to 32 years with a mean of $25.38 \pm 3.35$ years). Written informed consent was obtained from each subject. Table 4 describes the anthropometric characteristics of subjects during the study period. Participants were excluded if they were taking any medications, smoker and if they were diabetics. None of the subject had reported of taking $H$. sabdariffa L. beverage one month prior to the study and they were advised not to consume H. sabdariffa L. beverage from another source during the ex- 
perimental period. The consumption of the beverage covered two weeks period during which each subject consumed 1 litre a day (500 mL in the morning and $500 \mathrm{~mL}$ in the afternoon). No change happened in the normal food diet routine of the subjects; only $H$. sabdariffa L. beverage was added as a supplement. This protocol was approved by the National Ethics Committee of Cameroon according to the authorization N $107 / C N E / S E / 2012$.

\subsection{Blood Sample Collection and Preparation}

The collection of fasting blood sample were performed on days 0,7 and 14 between 6.00 and $8.00 \mathrm{AM}$ in the health centre "Espace priorité santé du Cameroun" at Dschang. Blood samples were collected in tubes with and without EDTA as anticoagulant. Serum was obtained after centrifugation of the blood collected in the tube without anticoagulant, and stored in Eppendorf tubes at $-18^{\circ} \mathrm{C}$ for further analyses. Blood collected in the tubes with anticoagulant was transported the same day at Penka-Michel's district hospital laboratory for haematological parameters investigation. The blood glucose level was also investigated the same day using serum obtained from the blood collected in tube without anticoagulant.

\subsection{Biochemical and Haematological Analyses}

Haematological parameters [red blood cell (RBC), packed cell volume (PCV), white blood cell (WBC), haemoglobin ( $\mathrm{Hb})$, mean corpuscular volume (MCV), mean corpuscular haemoglobin (MCH), mean corpuscular haemoglobin concentration (MCHC),lymphocytes, MID cells, granulocytes, platelet, mean platelet volume (MPV)] were measured using an automated haematological analyser, PE 600 (23 parameters). Triglycerides (TG) were measured using TECO DIAGNOSTICS kit (Lakeview Ave, Anaheim) while high density lipoprotein cholesterol (HDL-C) was measured using IMNESCO (Neustadt/Wied-Germany) kit. The concentration of low density lipoprotein cholesterol (LDL) was determined using the Friedewald formula [15]. Alanine aminotransferase (ALAT), aspartate aminotransferase (ASAT) and creatinine were measured using Hospitex Diagnostics kit (Osman Noro, Sesto Florentino), while serum iron, urea, glycaemia and total cholesterol (TC) were measured using CHRONOLAB kit (Barcelona, Spain).

\subsection{Statistical Analyses}

Results were reported as means \pm SD and statistical analyses were done using Graph pad prism version 5.00 software. The following statistical tests were performed: one way ANOVA and Newman-Keuls. A p value of less than .05 was considered significant.

\section{Results and Discussion}

\subsection{Results}

\subsubsection{Proximate and Mineral Composition of $H$. sabdariffa L. Dried Calyces}

Table 1 shows the proximate composition of $H$. sabdariffa L. dried calyces cultivated in West and Adamaoua regions of Cameroon. The dry matter, total protein, total lipid, total fiber and ash content of calyces harvested in the West region were respectively $93.09 \pm 0.06,5.98 \pm 0.11,10.10 \pm 0.23,22.30 \pm 0.15$ and $10.38 \pm 0.20 \%$ while the values $94.72 \pm 0.05,4.57 \pm 0.10,11.33 \pm 0.15,20.39 \pm 0.19$ and $9.15 \pm 0.19 \%$ were observed respectively for the dry matter, total protein, total lipid total fiber and ash content of calyces harvested in the Adamaoua region of Cameroon. The dry matter and crude lipid of calyces from Adamaoua region were significantly higher $(\mathrm{p}<0.05)$ than those of West region. However, the crude protein, crude fiber and ash content of calyces harvested in the West region were significantly higher $(\mathrm{p}<0.05)$ than those of Adamaoua region of

Table 1. Proximate composition of Hibiscus sabdariffa L. dried calyces (g/100g).

\begin{tabular}{ccccc}
\hline Sample & Dry matter & Crude protein & Crude lipid & Crude fibre \\
\hline CW & $93.09 \pm 0.06^{\mathrm{b}}$ & $5.98 \pm 0.11^{\mathrm{a}}$ & $10.10 \pm 0.23^{\mathrm{b}}$ & $22.30 \pm 0.15^{\mathrm{a}}$ \\
CA & $94.72 \pm 0.05^{\mathrm{a}}$ & $4.57 \pm 0.10^{\mathrm{b}}$ & $11.33 \pm 0.15^{\mathrm{a}}$ & $20.39 \pm 0.19^{\mathrm{b}}$ \\
\hline
\end{tabular}

Values are means \pm SD. Means in the same colon followed by different letters differ significantly at $5 \%$ probability. SD $=$ standard deviation, CW $=$ calyx from west region, $\mathrm{CA}=$ calyx from Adamaoua region. 
Cameroon. Table 2 shows the values of some mineral analysed in H. sabdariffa L. dried calyces harvested in two agro ecological areas in Cameroon. The mineral analysed were calcium, magnesium, potassium, sodium, phosphorus, iron and zinc. The values of these mineral ranged from 512.0 - 740.6, 77.8 - 177.7, 52.84 - 52.85, 1.1 - 2.1, 41.2 - 119.5, 3.25 - 8.20 and 0.56 - $17.5 \mathrm{mg} / 100 \mathrm{~g}$ respectively for $\mathrm{Ca}, \mathrm{Mg}, \mathrm{K}, \mathrm{Na}, \mathrm{P}, \mathrm{Fe}$ and $\mathrm{Zn}$. The observations show that $\mathrm{Mg}, \mathrm{Na}, \mathrm{P}, \mathrm{Fe}$ and $\mathrm{Zn}$ levels of dried calyces cultivated in West region of Cameroon were higher than those cultivated in the Adamaoua region.

\subsubsection{Phytochemical Composition of Aqueous and Methanol Extracts of Hibiscus sabdariffa L. Dried Calyces}

Several classes of secondary metabolites such as alkaloids, flavonoids, tannins, phenols and anthocyanins were identified both in the aqueous and methanol extracts of $H$. sabdariffa L. dried calyx (Table 3 ).

\subsubsection{Anthropometric Data of the Study Population}

The people recruited for this study were aged between 21 to 32 years old. The mean age of the study population was $25.38 \pm 3.35$ years while their mean height was $1.76 \pm 0.06 \mathrm{~m}$ (Table 4). Besides, the subjects mean weight were $69.23 \pm 6.87,68.38 \pm 7.25$ and $68.75 \pm 7.22 \mathrm{~kg}$ respectively for day 0: (D0), D7 and D14 while the mean

Table 2. Mineral composition of Hibiscus sabdariffa L. dried calyces (mg/100g).

\begin{tabular}{cccccccc}
\hline Sample & $\mathbf{C a}$ & $\mathbf{M g}$ & $\mathbf{K}$ & $\mathbf{N a}$ & $\mathbf{P}$ & $\mathbf{F e}$ & $\mathbf{Z n}$ \\
\hline $\mathbf{C A}$ & 740.6 & 77.8 & 52.85 & 1.10 & 41.2 & 3.25 & 0.56 \\
$\mathbf{C W}$ & 512.0 & 177.7 & 52.84 & 2.10 & 119.5 & 8.20 & 17.5 \\
\hline
\end{tabular}

$\mathrm{CA}=$ calyx from Adamaoua region, $\mathrm{CW}=$ calyx from west region, $\mathrm{Ca}=$ calcium, $\mathrm{Mg}=$ magnesium, $\mathrm{K}=$ potassium, $\mathrm{Na}=$ sodium, $\mathrm{P}=$ phosphorus, $\mathrm{Fe}=$ iron and $\mathrm{Zn}=$ zinc.

Table 3. Phytochemical screening of aqueous and methanol extracts of Hibiscus calyces.

\begin{tabular}{|c|c|c|c|c|c|c|c|c|}
\hline \multicolumn{9}{|c|}{ Class of compound } \\
\hline Sample & Alcaloids & flavonoids & tannins & saponins & sterols & triterpenoids & phenols & anthocyanines \\
\hline MECA & + & + & + & - & - & - & + & + \\
\hline AECA & + & + & + & - & - & - & + & + \\
\hline MECW & + & + & + & - & - & - & + & + \\
\hline EACW & + & + & + & - & - & - & + & + \\
\hline
\end{tabular}

MECA = methanolic extract of calyx from Adamaoua region, AECA = aqueous extract of calyx from Adamaoua region, MECW = methanolic extract of calyx from west region, EACA = aqueous extract of calyx from west region. + present, - absent.

Table 4. Characteristic data of the study population $(n=32)$.

\begin{tabular}{ccccccc} 
& \multicolumn{2}{c}{ Day 0 } & \multicolumn{2}{c}{ Day 7 } & \multicolumn{2}{c}{ Day 14 } \\
\cline { 2 - 6 } & Range & Means \pm SD & Range & Means \pm SD & Range & Means \pm SD \\
\hline Age (year) & $21-32$ & $25.38 \pm 3.35^{\mathrm{a}}$ & $21-32$ & $25.38 \pm 3.35^{\mathrm{a}}$ & $21-32$ & $25.38 \pm 3.35^{\mathrm{a}}$ \\
Height (m) & $1.60-1.82$ & $1.76 \pm 0.06^{\mathrm{a}}$ & $1.60-1.82$ & $1.76 \pm 0.06^{\mathrm{a}}$ & $1.60-1.82$ & $1.76 \pm 0.06^{\mathrm{a}}$ \\
Weight (kg) & $55.20-85.10$ & $69.23 \pm 6.87^{\mathrm{a}}$ & $55.60-84.40$ & $68.38 \pm 7.25^{\mathrm{a}}$ & $55.10-85$ & $68.75 \pm 7.22^{\mathrm{a}}$ \\
BMI (kg.m $\mathbf{- 2})$ & $19.79-24.78$ & $22.37 \pm 2.02^{\mathrm{a}}$ & $19.84-24.56$ & $22.08 \pm 1.99^{\mathrm{a}}$ & $19.75-24.75$ & $22.28 \pm 2.11^{\mathrm{a}}$ \\
$\mathbf{S P ~ ( \times 1 0 ~} \mathbf{~ m m H g )}$ & $9-12$ & $11.00 \pm 1.02^{\mathrm{a}}$ & $10-12$ & $11.06 \pm 0.76^{\mathrm{a}}$ & $9-12$ & $10.38 \pm 0.87^{\mathrm{b}}$ \\
$\mathbf{D P}(\times \mathbf{1 0} \mathbf{~ \mathbf { m H g } )}$ & $6-9$ & $7.18 \pm 0.82^{\mathrm{a}}$ & $4-7$ & $5.81 \pm 1.15^{\mathrm{b}}$ & $6-9$ & $6.87 \pm 0.94^{\mathrm{a}}$ \\
\hline
\end{tabular}

Values are means $\pm \mathrm{SD}(\mathrm{n}=32)$. Means in the same row followed by different letters differ significantly at $5 \%$ probability. $\mathrm{SD}=$ standard deviation, $\mathrm{BMI}=$ body mass index, $\mathrm{SP}=$ systolic pressure, $\mathrm{DP}=$ diastolic pressure. 
BMI were $22.37 \pm 2.02,22.08 \pm 1.99$ and $22.28 \pm 2.11 \mathrm{~kg} / \mathrm{m}^{2}$ for D0, D7 and D14 respectively (p $\left.>0.05\right)$. The systolic pressure decreased significantly $(\mathrm{p}<0.05)$ between D0 and D14 while there was a no significant decrease in diastolic pressure $(\mathrm{p}>0.05)$ between D0 and D14. The mean values of systolic pressure were $11.00 \pm$ $1.02,11.06 \pm 0.76$ and $10.38 \pm 0.87(\times 10 \mathrm{mmHg})$ respectively for D0, D7 and D14 while the mean values of diastolic pressure were $7.18 \pm 0.82,5.81 \pm 1.15$ and $6.87 \pm 0.94(\times 10 \mathrm{mmHg})$ respectively for D0, D7 and D14. In spite of the variation observed on blood pressure of study subjects, the values were within the normal range that is $<14(\times 10 \mathrm{mmHg})$ for Systolic pressure and $<9(\times 10 \mathrm{mmHg})$ for diastolic pressure.

\subsubsection{Effect of Hibiscus sabdariffa L. beverage Consumption on Hematological Parameters in Human Subjects}

The results of the effect of consumption of $H$. sabdariffa L. beverage on hematological parameters are show in Table 5. The H. sabdariffa L. dried calyces drink has a remarkable effect on red blood cells (RBC), Haemoglobin (Hb), pack cell volume (PCV) and white blood cells (WBC) as the mean values of these parameters changed significantly $(\mathrm{p}<0.05)$ during the study period. The mean values of RBC were $3.59 \pm 0.69,4.22 \pm 1.20$ and 4.62 $\pm 1.02\left(\times 10^{6} / \mu \mathrm{L}\right)$ for D0, D7 and D14 respectively. As for $\mathrm{Hb}$, the mean values were $11.45 \pm 2.45,13.51 \pm 3.86$ and $14.80 \pm 3.49(\mathrm{~g} / \mathrm{dL})$ for D0, D7 and D14 respectively while the mean values for PCV were $22.95 \pm 6.32$, $28.29 \pm 10.26$ and $31.94 \pm 8.47$ (\%) for D0, D7 and D14 respectively. There was not significant change (p > 0.05 ) on mean corpuscular volume (MCV), mean corpuscular hemoglobin (MCH), mean corpuscular hemoglobin concentration (MCHC), granulocytes, lymphocytes, platelet and mean platelet volume (MPV) values during the study period. However, the mean values of white blood cells (WBC) and MID cells decreased significantly $(\mathrm{p}<0.05)$. For WBC, mean values of $5.34 \pm 1.17,4.91 \pm 1.44$ and $4.37 \pm 0.79\left(\times 10^{3} / \mu \mathrm{L}\right)$ were obtained respectively for D0, D7 and D14 while for MID cells the mean values were $9.58 \pm 2.08,9.12 \pm 1.85$ and $8.37 \pm 2.06$ (\%) for D0, D7 and D14 respectively.

\subsubsection{Effect of Hibiscus sabdariffa L. Beverage Consumption on Biochemical Parameters in Human Subjects}

Biochemical parameters were assessed through the determination of the effect of $H$. sabdariffa L. beverage consumption on lipid profile, blood glucose, serum iron, and serum enzymes on the study subjects (Table 6). A complete lipid profile including total cholesterol (TC), triglycerides (TG), high density lipid cholesterol (HDL-C)

Table 5. Effect of Hibiscus sabdariffa L. tea drinking on hematological parameters in human.

\begin{tabular}{|c|c|c|c|}
\hline & Day 0 & Day 7 & Day 14 \\
\hline $\mathrm{RBC}\left(\times 10^{6} / \mu \mathrm{L}\right)$ & $3.59 \pm 0.69^{b}$ & $4.22 \pm 1.20^{\mathrm{a}}$ & $4.62 \pm 1.02^{\mathrm{a}}$ \\
\hline $\mathrm{Hb}(\mathrm{g} / \mathrm{dL})$ & $11.45 \pm 2.45^{\mathrm{b}}$ & $13.51 \pm 3.86^{\mathrm{a}}$ & $14.80 \pm 3.49^{\mathrm{a}}$ \\
\hline PCV (\%) & $22.95 \pm 6.32^{\mathrm{b}}$ & $28.29 \pm 10.26^{\mathrm{a}}$ & $31.94 \pm 8.47^{\mathrm{a}}$ \\
\hline $\operatorname{MCV}(\mathbf{f l})$ & $88.39 \pm 2.99^{\mathrm{a}}$ & $88.61 \pm 3.66^{\mathrm{a}}$ & $88.64 \pm 3.17^{\mathrm{a}}$ \\
\hline MCH (pg) & $32.34 \pm 1.75^{\mathrm{a}}$ & $32.07 \pm 1.58^{\mathrm{a}}$ & $32.41 \pm 1.69^{\mathrm{a}}$ \\
\hline MCHC (g/dL) & $36.67 \pm 0.99^{\mathrm{a}}$ & $36.20 \pm 1.17^{\mathrm{a}}$ & $36.64 \pm 1.27^{\mathrm{a}}$ \\
\hline WBC $\left(\times 10^{3} / \mu \mathrm{L}\right)$ & $5.34 \pm 1.17^{\mathrm{a}}$ & $4.91 \pm 1.44^{\mathrm{ab}}$ & $4.37 \pm 0.79^{b}$ \\
\hline Lymphocytes (\%) & $48.56 \pm 10.18^{\mathrm{a}}$ & $47.67 \pm 13.19^{\mathrm{a}}$ & $47.14 \pm 9.98^{\mathrm{a}}$ \\
\hline MID cells(\%) & $9.58 \pm 2.08^{\mathrm{a}}$ & $9.12 \pm 1.85^{\mathrm{ab}}$ & $8.37 \pm 2.06^{\mathrm{b}}$ \\
\hline Granulocytes (\%) & $41.86 \pm 10.46^{\mathrm{a}}$ & $43.15 \pm 14.21^{\mathrm{a}}$ & $45.52 \pm 15.00^{\mathrm{a}}$ \\
\hline Platelet $\left(\times 10^{3} / \mu \mathrm{L}\right)$ & $178.5 \pm 47.54^{\mathrm{a}}$ & $155.3 \pm 57.94^{\mathrm{a}}$ & $147.2 \pm 54.31^{\mathrm{a}}$ \\
\hline MPV (fl) & $10.19 \pm 0.53^{\mathrm{ab}}$ & $9.99 \pm 0.53^{\mathrm{b}}$ & $10.33 \pm 0.43^{\mathrm{a}}$ \\
\hline
\end{tabular}

Values are means \pm SD $(n=32)$. Means in the same row followed by different letters differ significantly at $5 \%$ probability. SD $=$ standard deviation, $\mathrm{RBC}=$ red blood cells, $\mathrm{Hb}=$ hemoglobin, $\mathrm{PCV}=$ pack cell volume (hematocrit), $\mathrm{MCV}=$ mean corpuscular volume, $\mathrm{MCH}=$ mean corpuscular hemoglobin, $\mathrm{MCHC}=$ mean corpuscular hemoglobin concentration, $\mathrm{WBC}=$ white blood cells, $\mathrm{MPV}=$ mean platelet volume. 
Table 6. Effect of Hibiscus sabdariffa L. tea consumption on some biochemical parameters in human.

\begin{tabular}{|c|c|c|c|}
\hline & Day 0 & Day 7 & Day 14 \\
\hline TC (mg/dL) & $134.1 \pm 40.32^{\mathrm{a}}$ & $130.5 \pm 37.25^{\mathrm{a}}$ & $101.7 \pm 19.57^{\mathrm{b}}$ \\
\hline HDL-C (mg/dL) & $32.05 \pm 8.94^{\mathrm{b}}$ & $36.00 \pm 7.89^{b}$ & $42.14 \pm 9.99^{\mathrm{a}}$ \\
\hline TG (mg/dL) & $46.80 \pm 33.40^{c}$ & $75.72 \pm 39.37^{\mathrm{b}}$ & $128.5 \pm 57.30^{\mathrm{a}}$ \\
\hline LDL-C (mg/dL) & $84.70 \pm 34.94^{\mathrm{a}}$ & $84.66 \pm 43.08^{\mathrm{a}}$ & $37.97 \pm 16.10^{\mathrm{b}}$ \\
\hline TC/HDL-C & $4.63 \pm 2.49^{\mathrm{a}}$ & $3.82 \pm 1.55^{\mathrm{a}}$ & $2.56 \pm 1.68^{b}$ \\
\hline LDL-C/HDL-C & $2.99 \pm 1.99^{\mathrm{a}}$ & $2.56 \pm 1.68^{\mathrm{a}}$ & $0.93 \pm 0.44^{b}$ \\
\hline Serum iron $(\mu \mathrm{g} / \mathrm{dL})$ & $101.1 \pm 33.50^{\mathrm{a}}$ & $100.8 \pm 43.17^{\mathrm{a}}$ & $108.6 \pm 35.77^{\mathrm{a}}$ \\
\hline Blood glucose (g/L) & $0.99 \pm 0.09^{\mathrm{a}}$ & $0.99 \pm 0.08^{\mathrm{a}}$ & $0.99 \pm 0.09^{\mathrm{a}}$ \\
\hline ASAT (UI /L) & $7.01 \pm 2.24^{\mathrm{a}}$ & $6.87 \pm 2.27^{\mathrm{a}}$ & $6.94 \pm 2.52^{\mathrm{a}}$ \\
\hline ALAT (UI/L) & $3.67 \pm 1.64^{\mathrm{a}}$ & $4.33 \pm 1.99^{\mathrm{a}}$ & $4.55 \pm 1.79^{\mathrm{a}}$ \\
\hline ASAT/ALAT & $2.36 \pm 1.46^{\mathrm{a}}$ & $1.94 \pm 0.91^{\mathrm{ab}}$ & $1.68 \pm 0.68^{\mathrm{b}}$ \\
\hline Creatinine (mg/dL) & $0.52 \pm 0.14^{b}$ & $0.69 \pm 0.12^{\mathrm{a}}$ & $0.71 \pm 0.14^{\mathrm{a}}$ \\
\hline Urea (mg/dL) & $19.06 \pm 7.00^{\mathrm{b}}$ & $23.29 \pm 6.55^{\mathrm{a}}$ & $20.80 \pm 6.45^{\mathrm{ab}}$ \\
\hline
\end{tabular}

Values are means \pm SD $(n=32)$. Means in the same row followed by different letters differ significantly at $5 \%$ probability. SD $=$ standard deviation, $\mathrm{TC}=$ total cholesterol, HDL-C $=$ high density lipoprotein cholesterol, TG = triglycerides, LDL-C = low density lipoprotein cholesterol, ASAT $=$ aspartate aminotransferase, ALAT = alanine aminotransferase.

was investigated and low density lipid cholesterol (LDL-C) as well as the TC/HDL-C and LDL-C/HDL-C ratios was calculated afterward. The TC, LDL-C, TC/HDL-C and LDL-C/HDL-C decreased significantly $(\mathrm{p}<0.05)$ during the study period. The average values of TC were $134.1 \pm 40.32,130.5 \pm 37.25$ and $101.7 \pm 19.57 \mathrm{mg} / \mathrm{dL}$ for D0, D7 and D14 respectively. On D0, D7 and D14 the mean values were respectively $84.70 \pm 34.94,84.66 \pm$ 43.08 and $37.97 \pm 16.10 \mathrm{mg} / \mathrm{dL}$ for LDL-C. The average serum TG level significantly increases from $46.80 \pm$ $33.40 \mathrm{mg} / \mathrm{dL}$ on D0 to $128.5 \pm 57.30 \mathrm{mg} / \mathrm{dL}$ on D14 ( $<0.05$ ). Besides, the HDL-C level also increases significantly ( $<0.05$ ) from $32.05 \pm 8.94 \mathrm{mg} / \mathrm{dL}$ on D0 to $42.14 \pm 9.99 \mathrm{mg} / \mathrm{dL}$ on D14. The results of serum iron, glycaemia, aspartate aminotransferase (ASAT), alanine aminotransferase (ALAT) and urea have shown no significant change $(p>0.05)$ during the test period. The ratio ASAT/ALAT and creatinine mean values were respectively decreasing and increasing significantly $(\mathrm{p}<0.05)$ during the study. For the ratio ASAT/ALAT, we obtained mean values of $2.36 \pm 1.46,1.94 \pm 0.91$ and $1.68 \pm 0.68$ for D0, D7 and D14 respectively. The mean values of serum creatinine were $0.52 \pm 0.14,0.69 \pm 0.12$ and $0.71 \pm 0.14 \mathrm{mg} / \mathrm{dL}$ respectively for D0, D7 and D14.

\subsection{Discussion}

\subsubsection{Proximate and Mineral Composition of Hibiscus sabdariffa L. Dried Calyces}

The chemical analysis of dried calyces harvested in the Adamaoua and West regions of Cameroon have shown that dry matter, crude protein, crude lipid, crude fiber and ash values respectively ranged from 93.09 - 94.72, 4.57 - 5.98, $10.10-11.33,20.39-22.30$ and 9.15\% - 10.38\%. These results were higher than those of Morton [16] who obtained the values $90.8,1.145,2.61,12.0$ and $6.90 \%$ respectively for dry matter, crude protein, crude lipid, crude fiber and ash. Adanlawo and Ajibade [17] and Amed [18] from their studies on the calyces from Nigeria have obtained the values of 12.24 and $94.9 \%$ for Ash and dry matter respectively. These values were higher than those we obtained. Bahaeldeen et al. [19] have found that the calyx from Sudan contain 89, 7.88, $0.16,13.20$ and $10.60 \%$ of dry matter, crude protein, crude lipid, crude fiber and ash respectively. These values were lower than those obtained in this study. The crude protein, crude fiber and ash levels of calyces harvested in the West region were significantly higher $(p<0.05)$ than those of Adamaoua region of Cameroon while the dry matter and total lipid of calyces from Adamaoua region were significantly higher $(p<0.05)$ than those of 
West region of Cameroon. These results might be due to the variable agro climatic conditions of the subject regions. The crude protein of $H$. sabdariffa L. calyx from the Western high plateaus zone of Cameroon was significantly higher $(\mathrm{p}<0.05)$ than that of high Guinean savanna zone. This result is in line with the findings of Modi [20] who reported that cool environmental conditions are associated with high total protein in leafy vegetables while hot temperature had a significant decrease in leaf protein content. Therefore, the higher temperatures and the long periods of drought in high Guinean savanna zone decrease the calyces crude protein levels harvested in this agro ecological zone of Cameroon. Hibiscus calyces harvested in the Western high plateaus zone recorded lower mean dry matter content of $93.09 \%$ than that of high Guinean savanna zone of $94.72 \%$. The high dry matter value recorded in calyx from high Guinean savanna zone may be due to the high temperature and long drought period which may be associated to high rate of evapotranspiration. In fact, during this period, the atmospheric humidity becomes very low in high Guinean savanna zone. The difference in relative humidity around the stomata and adjacent air regulates transpiration rates and pulls water up through the xylem tissues [21].

The results of mineral analysis have shown that the values ranged between 512.0 - 740.6, 77.8 - 177.7, 52.84 52.85, 1.10 - 2.10, 41.2 - 119.5, 3.25 - 8.20 and 0.56 - $17.5 \mathrm{mg} / 100 \mathrm{~g}$ respectively for calcium (Ca), magnesium $(\mathrm{Mg})$, potassium $(\mathrm{K})$, sodium $(\mathrm{Na})$, phosphorus $(\mathrm{P})$, iron $(\mathrm{Fe})$ and zinc $(\mathrm{Zn})$. These results were lower than the values 1583, 316, 2060, 5.5, 37.8 and $6.5 \mathrm{mg} / 100 \mathrm{~g}$ respectively for $\mathrm{Ca}, \mathrm{Mg}, \mathrm{K}, \mathrm{Na}$, Fe and Zn obtained by Mady et al. [22] with the calyx cultivated in Nigeria. However, except the Na content (96.66 mg/100g), these results were higher than the values 49.35, 12.65, 38.65, 3.22, 12.22 and $36.30 \mathrm{mg} / 100 \mathrm{~g}$ obtained by Adanlawo and Ajibade [17] respectively for $\mathrm{K}, \mathrm{Ca}, \mathrm{Mg}, \mathrm{Fe}, \mathrm{Zn}$ and $\mathrm{P}$. The effect of agro ecological area is observable with $\mathrm{Hi}$ biscus sabdariffa L. calyx mineral composition. Except the $\mathrm{K}$ and Ca content, the Mg, Na, P, Fe and Zn levels of Hibiscus sabdariffa L. calyx harvested in the West region of Cameroon (Western high plateaus zone) were higher than those of Adamaoua region of Cameroon (high Guinean savanna zone). This may be attributed to the variable uptake of minerals by plant material and variable agro climatic conditions of study areas. The long dry season in the high Guinean savanna makes soils dry for longer periods of time inhibiting the absorption of soil nutrients for plant development [23].

\subsubsection{Phytochemical Composition of Aqueous and Methanol Extracts of H. Sabdariffa L. Dried Calyces}

The Phytochemical screening performed on aqueous and methanol extracts has shown the presence of different classes of chemical compounds such as anthocyanins, alkaloids, flavonoids, tannins and phenols. Most phytochemical compounds are known to have positive effect on health and general wellbeing. Anthocyanins may provide protection from DNA cleavage, altering development of hormone-dependent disease symptoms, boosting production of cytokines, anti-inflammatory activity, antimicrobial infections, oxidative stress protection and inhibition of both body weight and adipose tissue increases [24]. Beside, tannins in plants have been shown to confer antidiarrheal and anti-hemorrhagic properties [25], while saponins have been reported to have antifungal properties [26]. Polyphenols can chelate pro-oxidant metal ions, such as iron and copper, thus preventing free radical formation from these pro-oxidants [27], though flavonoids are known to be synthesized by plants in response to microbial infection and it should not be surprising that they have been found in vitro to be effective antimicrobial substances against a wide array of microorganisms [28]. Moreover, flavonoids are known to have antioxidant effects and have been shown to inhibit the initiation, promotion, and progression of tumors [29]. Therefore, most of medicinal properties (antioxidant, antibacterial, anti-inflammatory, cardio protective, antihypertensive, glucose blood lowering effects, etc.) affected to $H$. sabdariffa L. calyx might be possible favor to phytochemical compounds present in this plant.

\subsubsection{Anthropometric Data of the Study Population}

One of the specific objectives of this study was to evaluate the effect of drinking $H$. sabdariffa L. calyxes' beverageon blood pressure and body mass index (BMI) of the participant. At the beginning (day 0) of the study, the mean values of weight, BMI, SP (systolic pressure) and DP (diastolic pressure) were respectively $69.23 \pm$ $6.87 \mathrm{~kg}, 22.37 \pm 2.02 \mathrm{~kg} \cdot \mathrm{m}^{2}, 11.00 \pm 1.02(\times 10 \mathrm{mmHg})$ and $7.18 \pm 0.82(\times 10 \mathrm{mmHg})$. At the end of the study (day 14), the observations have shown a significant decrease of SP $(\mathrm{p}<0.05)$ and a decrease of DP, BMI and weight ( $p>0.05$ ) with the respective mean values of $10.38 \pm 0.87(\times 10 \mathrm{mmHg}), 6.87 \pm 0.94(\times 10 \mathrm{mmHg}), 22.28$ $\pm 2.11 \mathrm{~kg} \cdot \mathrm{m}^{2}$ and $68.75 \pm 7.22 \mathrm{~kg}$. These results were similar to those obtained by Mckay et al. [6], who used a 
randomized, double-blind, placebo-controlled clinical trial to test the effect of $H$. sabdariffa L. tea (tisane) in prehypertensive and mildly hypertensive 65 adults aged between 30 - 70 years. Each subject consumed $1.25 \mathrm{~g} \mathrm{H}$. sabdariffa L./240mL boiled water three times day during six weeks. They observed that the change in SP among participants who consumed the hibiscus tea was greater than in participants who consumed the placebo beverage. The change in DP after treatment was not significant between the placebo and hibiscus groups. Besides, Mozaffari-Khosravi et al. [30] tested 27 persons with mean age of $55.37 \pm 8.6$ years who consumed $2 \mathrm{~g}$ hibiscus tea/240mL boiling water with $5 \mathrm{~g}$ sugar twice day during 30 days. They observed a statistically significant decrease of SP and a non-significant decrease of DP, weight and BMI during the test period. Their values were ranged between 134.4 - $112.7(\mathrm{mmHg}), 81.6$ - $80.5(\mathrm{mmHg}), 28.3$ - $28.0\left(\mathrm{~kg} \cdot \mathrm{m}^{2}\right)$ and 70.4 - $69.9 \mathrm{~kg}$ respectively for SP, DP, BMI and weight from basal to day 30. Furthermore, in the study of Haji and Haji [31], two groups of patients suffering from hypertension consumed sour tea (ST) and black tea (BT) for 15 days. The patient's mean age was 52 years and the treatment group consumed 1 glass daily of $H$. sabdariffa $L$. tea prepared with 2 spoonful's of blended tea per glass brewed in boiling water for 20 - 30 min. This study showed that 12 days after the intervention, SP and DP in the ST consumers decreased respectively by $11.2 \%$ and $10.7 \%$ and after three days of withdrawal, the SP and DP increased by 7.6 and 5.6\% respectively. Hibiscus tea possesses an antihypertensive activity and its consumption could not significantly affect body weight changes.

\subsubsection{Effect of $H$. sabdariffa L. Beverage Drinking on Hematological Parameters in Human Subjects} The assessment of hematological parameters could be used to reveal the benefit or deleterious effects of foreign compounds like hibiscus tea on the blood constituents of animal or human subjects. The significant $(\mathrm{p}<0.05)$ elevation observed in the levels of RBC, $\mathrm{Hb}$ and PCV clearly indicates that the beverage contains phytochemical compounds that stimulate the formation of erythropoietin in the stem cells (erythropoiesis) as well as the decreasing in the destruction of matured RBC during the study period. Erythropoietin is a glycoprotein which stimulates stem cells in bone marrow to produce red blood cells [32]. The Hibiscus calyx extract have been shown to contain anthocyanins as it is known to induce the renal secretion of erythropoietin [33] [34]. These results are similar to those of Ejere et al. [35] who observed significant $(\mathrm{p}<0.05)$ increase in RBC, Hb and PCV values in rats following their study on the effect of aqueous extract of $H$. sabdariffa L. calyces on the hematological profile of normal male albino rats. The increase of $\mathrm{Hb}$ and PCV is indicative of the fact that oxygen uptake and transfer was very adequate in the patients [36]. The significant increase $(\mathrm{p}<0.05)$ of $\mathrm{Hb}$ value also corroborate our previous results [7]. There was no significant ( $p>0.05$ ) variation on MCH, MCV and MCHC values during the study period. This may be explained by the fact that MCHC, MCV and MCH relate to individual red blood cells while PCV, Hb and RBC count relate to the total population of red blood cells in the blood [37]. These results were at variance with those of Ejere et al. [35] who state that the effects of aqueous extract of Hibiscus sabdariffa calyces on hematological characteristics of rattus norvergicus shown significant increase $(\mathrm{p}<0.05)$ on MCHC, MCV and MCH. Besides, the effect of consumption of Hibiscus tea have no significant change on platelet, MPV, granulocytes and lymphocytes but a significant decrease $(\mathrm{p}<0.05)$ on WBC and MID cells values. The WBC count and indices have been known to play important roles in improving the immune system and also in protection of body cells against pathogens. However, In spite of the significant decrease of WBC and MID cells during the study period, the values of these parameters were in the normal range that is $4-10$ $\left(\times 10^{3} / \mu \mathrm{L}\right)$ and $1.0 \%-15.0 \%$ respectively for WBC and MID cells. The results indicate that the participant remained healthy because decrease in number of WBC below the normal range is an indication of allergic conditions and certain parasitism or presence of foreign body in circulating system [38]. But none of this was observed during this study. These results not corroborated the findings of Ejere et al. [35] who observed a significant increase $(\mathrm{p}<0.05)$ of WBC value of rats following treatment with aqueous $H$. sabdariffa calyx L. extracts. Barger [39] reported that any increase in MCV, MCH and decrease in MCHC above or below the normal range indicate macrocytic and hypochromic anemia, probably due to the increase activity of bone marrow and deficiency of some hematopoietic factors which are useful index of the capacity of bone marrow to produce red blood cells. In this study, even though the MCV and MCH values increased and MCHC value decreased, these values were in the normal range that is 80 - $99 \mathrm{fl}, 26$ - $32 \mathrm{pg}$ and 32 - $36 \mathrm{~g} / \mathrm{dL}$ respectively for MCV, MCH and MCHC. In short, H. sabdariffa L. calyx extracts from Cameroon might be beneficial to the hematopoietic system.

\subsubsection{Effect of $H$. sabdariffa L. Drinking Beverage on Biochemical Parameters in Human Subjects}

Plasma lipid disorders characterized by hypercholesterolemia are the most prevalent indicator for susceptibility 
to cardiovascular diseases. It is characterized by alterations occurring in serum lipid and lipoprotein profile due to increase concentrations of total cholesterol (TC), low density lipoprotein cholesterol (LDL-C), very low density lipoprotein cholesterol (VLDL-C) and triglycerides (TG) with a concomitant decrease in the concentrations of high density lipoprotein cholesterol (HDL-C) in the blood circulation [40]. During this study, there were a significant decrease $(\mathrm{p}<0.05)$ of TC and LDL-C values and a significant increase $(\mathrm{p}<0.05)$ of HDL-C and TG values. The result of TC is similar to that of Tzu-Li et al. [41] who investigated the cholesterol-lowering potential of Hibiscus extract in human subject, a clinical study using oral preparation of Hibiscus capsules and using 42 volunteers aged between 18 - 75 years during 4 weeks. They observed that a dosage of two capsules of Hibiscus extract for one month significantly lower the serum cholesterol level. Pooja and Priscilla [42] also observed in their study that the groups of rats treated with extract of calyces and leaves of $H$. sabdariffa L. showed a significant decrease in the serum TC, LDL-C, VLDL-C and TG values along with an increase in serum HDL-C levels. Furthermore, in this study we observed a significant decrease $(\mathrm{p}<0.05)$ of TC/HDL-C and LDL-C/HDL-C ratios which are also the best indicators of cardiovascular diseases risk. The normal values are $<5$ and $<3.5$ for TC/HDL-C and LDL-C/HDL-C ratios respectively. The result of artherogenic index, LDL-C/ HDL-C was similar to that of Pooja and Priscilla [42]. Therefore the H. sabdariffa L. drink may be used in the prevention of cardiovascular diseases.

Iron is the micronutrient necessary for respiratory gas transport via hemoglobin. In this study we observed an increase ( $p>0.05$ ) of serum iron value. As this value increased, it follows the same trend like hemoglobin concentration; therefore the profit is the organism capacity to transport oxygen and to increase vital capacity of $H$. sabdariffa L. consumers. Besides, the blood glucose level of the studied subjects was permanent during the study. Therefore, there is no fear that the drink could have hyperglycemic property because of the sugar used in its preparation. Adrian et al. [43] in order to investigate the efficacy of $H$. Sabdariffa L. beverage as a means of reducing post-prandial blood glucose levels in human subjects have shown in their study that $H$. sabdariffa L. tea appears to have an effect in terms of slowing the rate of rise in blood glucose following consumption of high glycemic index food. The hypoglycemia effect of Hibiscus tea might be linked to the fact that $H$. sabdariffa $\mathrm{L}$. tea has been shown to have a pancreatic $\alpha$-amylase inhibitory action, which appears to be attributable to its hibiscus acid content [44].

ASAT and ALAT are enzymes generally used in the diagnostic of liver function integrity while creatinine and urea are used for kidney. The increase in these enzymes is a sign of deterioration of these organs. During this study, we observed a decrease ( $p>0.05)$ in ASAT, an increase ( $p>0.05)$ of ALAT, urea and a significant increase $(\mathrm{p}<0.05)$ in creatinine. In spite of the variations observed, all the values of these parameters were in the normal range for men that is $<35,<45$ (UI/L), $0.7-1.20$ and $15-45 \mathrm{mg} / \mathrm{dL}$ respectively for ASAT, ALAT, creatinine and urea; therefore the consumption of this tea could have some beneficial effect for liver and kidney functions. Ologundudu et al. [45] in their study have shown that the Hibiscus anthocyanins extract significantly lowered the serum levels of the hepatic enzymes ASAT and ALAT and also reduced oxidative liver damage. Moreover, Onyenekwe et al. [46] have showed that water extract of Hibiscus calyx decrease serum creatinine levels in spontaneously hypertensive and normotensive rats. The ASAT/ALAT ratio is a diagnostic marker of liver disease. The value $<1$ suggested nonalcoholic steatohepatitis while a ratio $\geq 2$ strongly suggest an alcoholic liver disease [47]. In this study there was a significant decrease $(\mathrm{p}<0.05)$ in ASAT/ALAT ratio from $2.36 \pm$ 1.46 to $1.68 \pm 0.68$. The decrease in this ratio is indicative of hepatoprotective role of $H$. sabdariffa L. drink tea in studied subjects.

\section{Conclusion}

The present study indicated that $H$. sabdariffa L. calyces from Cameroon are important source of crude fiber and minerals. Phytochemical screening test has revealed the presence of bioactive compounds such as alkaloid, flavonoids, tannins, phenols and anthocyanins. The in vivo studies have shown that consumption of $H$. sabdariffa L. aqueous extract might have an antihypertensive activity and boost the hematopoietic system therefore is useful in the prevention of anemia and also might have a cardio protective effect. There were no risks on immune system function and also on liver and kidney functions as well as serum enzymes were concerned.

\section{Acknowledgements}

The authors thank the volunteer participants for their consent. 


\section{Conflict of Interest}

The authors declare no conflict of interest.

\section{References}

[1] Kromhout, D., Bloemberg, B.P., Feskens, E.J., Hertog, M.G., Menotti, A. and Blackburn, H. (1996) Alcohol, Fish, Fiber and Antioxidant Vitamins Intake Do Not Explain Population Differences in Coronary Heart Disease Mortality. International Journal of Epidemiology, 25, 753-759. http://dx.doi.org/10.1093/ije/25.4.753

[2] ILSI (1999) Safety Assessment and Potential Health Benefits of Food Components Based on Selected Scientific Criteria. ILSI North America Technical Committee on Food Components for Health Promotion. Critical Reviews in Food Science and Nutrition, 39, 203-216. http://dx.doi.org/10.1080/10408699991279169

[3] Agea, J.B., Kimondo, J.M., Okia, C.A., Abohassan, R.A., Obua, J., Hall, J. and Teklehaimanot, Z. (2010) Contribution of Wild and Semi Food Plants to Overall House Hold Diet in Bunyoro-Kitara Kingdom, Uganda. Agricultural Journal, 6, 134-144.

[4] Babalola, S.O., Babalola, A.O. and Aworh, O.C. (2000) Compositional Attributes of the Calyces of Roselle (Hibiscus sabdariffa L.). Journal of Food Technology in Africa, 6, 133-134.

[5] Wong, P., Salmah, Y.H.M. and Cheman, Y.B. (2002) Physico-Chemical Characteristics of Roselle (Hibiscus sabdariffa L.). Nutrition \& Food Science, 32, 68-73. http://dx.doi.org/10.1108/00346650210416994

[6] Mckay, D.L., Oliver Chen, C.Y., Saltzman, E. and Blumberg, J.B. (2010) Hibiscus sabdariffa L. Tea Lowers Blood Pressure in Pre Hypertensive and Mildly Hypertensive Adults. The Journal of Nutrition, 140, 298-303. http://dx.doi.org/10.3945/jn.109.115097

[7] Maffo, T.G., Etamé, L.G., Pankoui, M.J.B., Feukeng, M., Fotso, M.K.H., Tchouanguep, M.F. and Gouado, I. (2011) Effect of Folere Juice (Calyx of Hibiscus sabdariffa Lin) on Some Biochemical Parameters in Humans. Pakistan Journal of Nutrition, 10, 755-759. http://dx.doi.org/10.3923/pjn.2011.755.759

[8] Harbone, J.B. (1973) Phytochemical Methods. In: A Guide to Modern Techniques of Plant Analysis, Chapman and Hall Ltd., London, 116.

[9] AOAC (1990) Association of Official Analytical Chemists. Official Methods of Analysis. 15th Edition, Washington DC.

[10] Dorée, C. (1999) Les méthodes de la chimie de la cellulose. DUNOT, Paris. 406 p.

[11] Egan, H., Kirk, R.S. and Sawyer, R. (1981) Pearson's Chemical Analysis of Foods. 8th Edition, Churchill Livingstone, London, New York.

[12] Pauwels, J.M., Van Panst, E., Verloo, M. and Mvondo Zé, A. (1992) Manuel de Laboratoire de Pédologie - méthodes d'analyses de sols et de plantes; équipement et gestion des stocks de verrerie et de produits chimiques. Publications Agricoles nr. 28, A.G.C.D., Bruxelles, Belgium, 180 p. http://hdl.handle.net/1854/LU-223183

[13] Chapman, H.D. and Pratt, F.P. (1961) Calcium and Magnesium by Titration Methods. In: Chapman, H.D. and Pratt, F.P., Eds., Methods of Analysis for Soils, Plants and Water, University of California, Public Division of Agricultural Sciences, Berkeley, 20.

[14] Chapman, H.D. and Pratt, F.P. (1968) Ammonium Molybdate-Ammonium Vandate Method for Determination of Phosphorus. In: Chapman, H.D. and Pratt, F.P., Eds., Methods of Analysis for Soils, Plants and Water, University of California, Public Division of Agricultural Sciences, Berkeley, 169-170.

[15] Friedewald, W.T., Levy, R.I. and Frederickson, D.S. (1972) Estimation of Concentration of the Low Density Lipoprotein Cholesterol in Plasma, without Use of Preparative Ultracentrifuge. Clinical Chemistry, 18, 499-502.

[16] Morton, J.F. (1987) Roselle. In: Dowling Jr., C.F., Ed., Fruits of Warm Climates, Media Inc., Greensboro, $281-286$.

[17] Adanlawo, I.G. and Ajibade, V.A. (2006) Nutritive Value of Two Varieties of Roselle (Hibiscus sabdariffa) Calyces Soaked with Wood Ash. Pakistan Journal of Nutrition, 5, 555-557. http://dx.doi.org/10.3923/pjn.2006.555.557

[18] Amed, A.O., Isa, M.T., Ahmed, A.S. and Adamu, S.B. (2009) Studies on the Use of Trona in Improving the Taste of the Extract from Hibiscus sabdariffa Calyx. Nigerian Journal of Pharmaceutical Sciences, 8, 7-12.

[19] Bahaeldeen, B.M., Abdelatif, A.S. and Abdelhafiz, A.D. (2012) Roselle (Hibiscus sabdariffa L.) in Sudan, Cultivation and Their Uses. Bulletin of Environment, Pharmacology and Life Sciences, 1, 48-54.

[20] Modi, A.T. (2007) Growth Temperature and Plant Age Influence on Nutritional Quality of Amaranthus Leaves and Seed Germination Capacity. Crop Science, School of Agricultural Sciences and Agribusiness, University of KwaZuluNatal, Scottsville, South Africa.

[21] Taiz, L. and Zeiger, E. (2002) Plant Physiology. 3rd Edition, Sinauer Associates Inc., Sunderland, 555-557. 
[22] Mady, C., Manuel, D., Mama, S., Augustin, N., Max, R. and Oumar, S. (2009) Le Bissap (Hibiscus sabdariffa L.): Composition et Principales Utilisations. Fruits, 64, 179-193. http://dx.doi.org/10.1051/fruits/2009013

[23] Asante, W.J., Nasare, I.L., Tom-Dery, D., Ochire-Boadu, K. and Kentil, K.B. (2014) Nutrient Composition of Moringa oleifera Leaves from Two Agro Ecological Zones in Ghana. African Journal of Plant Science, 8, 65-71. http://dx.doi.org/10.5897/AJPS2012.0727

[24] Mary, A.L. (2004) Anthocyanins and Human Health: An in Vitro Investigative Approach. Journal of Biomedicine and Biotechnology, 5, 306-313.

[25] Asquith, T.N. and Butler, L.G. (1986) Interactions of Condensed Tannins with Selected Proteins. Photochemistry, 25, 1591-1593. http://dx.doi.org/10.1016/S0031-9422(00)81214-5

[26] Osuagwu, G.G.E., Okwulehie, I.C. and Emenike, J.O. (2007) Photochemical and Mineral Content of the Leaves of Four Nigerian Pterocarpus species. International Journal of Molecular Medicine and Advance Sciences, 3, 6-11.

[27] Kris-Etherton, P.M., Hecker, K.D., Bonanome, A., Coval, S.M., Binkoski, A.E., Hilpert, K.F., Griel, A.E. and Etherton, T.D. (2002) Bioactive Compounds in Foods: Their Role in the Prevention of Cardiovascular Disease and Cancer. American Journal of Medicine, 113, 71S-88S. http://dx.doi.org/10.1016/S0002-9343(01)00995-0

[28] Alaa, G.A. (2012) Antioxidant and Antibacterial Activities of Hibiscus sabdariffa L. Extracts. African Journal of Food Science, 6, 506-511.

[29] Kim, S.Y., Kim, J.H., Kim, S.K., Ohandy, M.J. and Jung, M.Y. (1994) Antioxidant Activities of Selected Oriental Herb Extracts. Journal of the American Oil Chemists' Society, 71, 633-640. http://dx.doi.org/10.1007/BF02540592

[30] Mozaffari-Khosravi, H., Jalali-Khanabadi, B.A., Afkhami-Ardekani, M., Fatehi, F. and Noori-Shadkam, M. (2009) The Effects of Sour Tea (Hibiscus sabdariffa) on Hypertension in Patients with Type II Diabetes. Journal of Human Hypertension, 23, 48-54. http://dx.doi.org/10.1038/jhh.2008.100

[31] Haji Faraji, M. and Haji Tarkhani, A.H. (1999) The Effect of Sour Tea (Hibiscus sabdariffa) on Essential Hypertension. Journal of Ethnopharmacology, 65, 231-236. http://dx.doi.org/10.1016/S0378-8741(98)00157-3

[32] Ohlsson, A. and Aher, S.M. (2009) Early Erythropoietin for Preventing Red Blood Cells Transfusion in Preterm and/or Low Birth Weight Infants. Journal of Dietary Supplements, 6, 227-251.

[33] Heda, G.L. and Bhatia, A.L. (1986) Hemocytometrical Changes in Swiss Albino Mice after Intrauterine Low Level HTO Exposure. Proc. Asian Reg. Conf. Med. Phys, 390.

[34] Kaur, C. and Kapoor, H.C. (2005) Antioxidant Activity of Some Fruits in Indian Diet. Acta Horticulturae, 696, 563-565. VII International Symposium on Temperate Zone Fruits in the Tropics and Subtropics-Part Two. http://www.actahort.org/books/696/696_99.htm http://dx.doi.org/10.17660/actahortic.2005.696.99

[35] Ejere, V.C., Nnamonu, E.I., Chukwuka, C.O., Ugwu, G.C., Ejim, A.O. and Asogwa, C.N. (2013) Effects of Aqueous Extract of Hibiscus sabdariffa Calyces on Hematological Characteristics of Rattus Novergicus. Animal Research International, 10, 1809-1816.

[36] Ots, I., Murumagi, A. and Horak, P. (1998) Hematological Health State Indices of Reproducing Great Tits: Methodology and Sources of Natural Variation. Functional Ecology, 12, 700-707. http://dx.doi.org/10.1046/j.1365-2435.1998.00219.x

[37] Adebayo, J.O., Adesokan, A.A., Olatunji, L.A., Burro, D.O. and Soladoye, A.O. (2005) Effect of Ethanolic Extract of Bougainvillea spectabilis Leaves on Hematological and Serum Lipid Variables in Rats. Biochemistry, 17, 45-50.

[38] Ahamefule, F.O., Obua, B.E., Ukweni, I.A., Oguike, M.A. and Amaka, R.A. (2008) Hematological and Biochemical Profile of Weaner Rabbits Fed Raw or Processed Pigeon Pea Seed Meal Based Diets. African Journal of Agricultural Research, 3, 315-319.

[39] Barger, A.M. (2003) The Complete Blood Cell Count: A Powerful Diagnostic Tool. Veterinary Clinics of North America: Small Animal Practice, 33, 1207-1222. http://dx.doi.org/10.1016/S0195-5616(03)00100-1

[40] Dhuley, J., Naik, S.R., Rele, S. and Banerji, A. (1999) Hypo Lipidemic and Antioxidant Activity of Di Allyl Disulphide in Rats. Pharmacy and Pharmacology Communications, 5, 689.

[41] Lin, T.-L., Lin, H.-H., Chen, C.-C., Lin, M.-C., Chou, M.-C. and Wang, C.-J. (2007) Hibiscus sabdariffa Extract Reduces Serum Cholesterol in Men and Women. Nutrition Research, 27, 140-145. http://dx.doi.org/10.1016/j.nutres.2007.01.007

[42] Pooja, C.O. and Priscilla, D.M. (2009) Antioxidant and Anti Hyperlipidemic Activity of Hibiscus sabdariffa Linn. Leaves and Calyces Extracts in Rats. Indian Journal of Experimental Biology, 47, 276-282.

[43] Adrian, P.H., Ross, G.C., Moustafa, A.S. and Usama, A. (2009) The Efficacity of Karkadey Tea in Controlling PostPrandial Blood Glucose Levels. American Journal of Pharmacology and Toxicology, 4, 151-157. http://dx.doi.org/10.3844/ajptsp.2009.151.157 
[44] Hansawasdi, C., Kawabata, J. and Kasai, T. (2000) Alpha-Amylase Inhibitors from Roselle (Hibiscus sabdariffa Linn) Tea. Bioscience, Biotechnology, and Biochemistry, 64, 1041-1043. http://dx.doi.org/10.1271/bbb.64.1041

[45] Ologundudu, A., Ologundudu, A.O., Ololade, I.A. and Obi, F.O. (2009) Effect of Hibiscus sabdariffa Anthocyanins on 2,4-Dinitrophenylhydrazine-Induced Hepatotoxicity in Rabbits. International Journal of Physical Sciences, 4, 233237.

[46] Onyenekwe, P.C., Ajani, E.O., Ameh, D.A. and Gamaniel, K.S. (1999) Antihypertensive Effect of Roselle (Hibiscus sabdariffa) Calyx Infusion in Spontaneously Hypertensive Rats and a Comparison of Its Toxicity with That in Wistar Rats. Cell Biochemistry and Function, 17, 199-206. http://dx.doi.org/10.1002/(SICI)1099-0844(199909)17:3<199::AID-CBF829>3.0.CO;2-2

[47] Qiang, L., Xiaoli, L., Shuhua, L., Changshun, X., Yali, L. and Chunming, M. (2012) The Relationship between AST/ALT Ratio and Metabolic Syndrome in Han Young Adults-AST/ALT Ratio and Metabolic Syndrome. Recent Advances in Cardiovascular Risk Factors, 12, 248-254. 